\title{
Effect of Sodium Citrate on Growth of Bacteria in Blood Culture
}

\author{
Dong-Hyun Lee ${ }^{1}$, Eun-Ha Koh', Sae-Rom Choi ${ }^{1}$, Sunjoo Kim¹, Dong Hoon Kim², Nam Yong Lee ${ }^{3}$ \\ Departments of ${ }^{1}$ Laboratory Medicine, ${ }^{2}$ Emergency Medicine, Gyeongsang Institute of Health Sciences, \\ Gyeongsang National University School of Medicine, Jinju, ${ }^{3}$ Department of Laboratory Medicine, \\ Samsung Medical Center, Sungkyunkwan University School of Medicine, Seoul, Korea
}

Background: This study compared the growth of Staphylococcus aureus, Escherichia coli, Pseudomonas aeruginosa, Streptococcus pneumoniae, and Haemophilus influenzae in blood culture bottles containing anticoagulants, sodium polyanethol sulfonate (SPS) and sodium citrate.

Methods: One hundred and fifty colony forming units of five different bacterial species were inoculated into standard aerobic (SA) and standard anaerobic (SN) bottles and were combined with $5 \mathrm{~mL}$ of human blood in solution with SPS or sodium citrate. Time to detection (TTD) was then monitored using the BacT/ Alert 3D system (bioMerieux Inc.).

Results: Compared to the bacteria-only controls, cultures containing $S$. aureus, E. coli, $P$. aeruginosa, and $S$. pneumoniae plus SPS blood or citrated blood trended toward reduced TTD in both SA and SN bot- tles; however, there was no significant difference in TTD between SPS and sodium citrate anticoagulant. Although $H$. influenzae showed a remarkable difference in TTD between SPS (SA $14.8 \mathrm{~h}$, SN $15.0 \mathrm{~h}$ ) and sodium citrate (SA $23.5 \mathrm{~h}$, SN $18.3 \mathrm{~h}$ ), this difference was not statistically significant $(P=0.10)$. Conclusion: Addition of blood enhanced growth of bacteria. All experimental bacteria except $H$. influenzae showed similar TTD in SPS blood and citrated blood. These results support the usefulness of sodium citrate anticoagulant for artificial inoculation in blood culture bottles. (Ann Clin Microbiol 2013;16: 168-173)

Key Words: Anticolagulants, Bacteremia, Blood, Culture, Sodium citrate

\section{INTRODUCTION}

Despite its widespread use as an anticoagulant for blood culture $[1,2]$, sodium polyanethol sulfonate (SPS) is not commonly used in other laboratory analyses. The establishment of an artificial blood culture model is complicated by the difficulties associated with large-scale SPS anticoagulant preparation for phlebotomy. During blood donation, collection bags usually contain sodium citrate as an anticoagulant. Given the many phlebotomies of polycythemia patients in large hospital settings, it would be preferable to use sodium citrated blood in bacteremia analyses. Citrate, heparin, and EDTA are known to be toxic to microorganisms in blood culture [1,3]. However, if the inhibitory effect of citrate on bacterial growth is minimal compared to that of SPS, sodium citrate might be an acceptable alternative for in vitro bacteremia detection. We compared the growth of bacteria in the absence of blood to bacterial growth following spiking with SPS or citrate-treated whole blood samples. To our knowledge, no previous studies have directly compared the effects of SPS and citrate on bacterial growth in blood culture. Staphylococcus aureus and Eschericia coli which are the most common pathogens causing sepsis in Korea [4] were used for the experiment. Pseudomonas aeruginosa, an absolute aerobe, as well as Streptococcus pneumoniae and Haemophilus influenzae, two fastidious organisms, were also included. As the blood culture bottles could be entered to the automatic blood culture machine several hours after inoculated with blood, we contrived preincubation of these bottles either at room temperature or $37^{\circ} \mathrm{C}$ to see the effect of delayed entry on the growth of bacteria.

Received 13 August, 2012, Revised 6 November, 2013, Accepted 7 November, 2013

Correspondence: Sunjoo Kim, Department of Laboratory Medicine, Gyeongsang National University School of Medicine, 79 Gangnam-ro, Jinju 660-702, Korea. (Tel) 82-55-750-8239, (Fax) 82-55-762-2696, (E-mail) sjkim8239@hanmail.net

(c) The Korean Society of Clinical Microbiology.

() This is an Open Access article distributed under the terms of the Creative Commons Attribution Non-Commercial License (http://creativecommons.org/licenses/by-nc/3.0) which permits unrestricted non-commercial use, distribution, and reproduction in any medium, provided the original work is properly cited 


\section{MATERIALS AND METHODS}

\section{Bacterial preparation}

Standard aerobic (SA) and standard anaerobic (SN) bottles (bioMerieux Inc., Marcy l'Etoile, France) were inoculated with 150 colony forming units (CFU) of S. aureus (ATCC 29213) and E. coli (ATCC 25922); S. pneumoniae and H. influenzae (clinical isolates) prepared in brain heart infusion broth. For $P$. aeruginosa (clinical isolate), an absolute aerobe, only SA bottles were used for the experiment. The same experiment was repeated three times on separate days. $S$. aureus grew on blood agar plates (BAP) to a mean \pm SD CFU of $170 \pm 45$; E. coli on MacConkey agar plates to a mean CFU of $150 \pm 25$; P. aerugino-

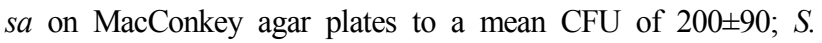
pneumoniae on BAP to a mean CFU of $160 \pm 77$; H. influenzae on chocolate agar plates to a mean CFU of $150 \pm 67$.

\section{Preparation of anticoagulated blood}

A solution of SPS was prepared by adding $1,320 \mathrm{mg}$ of SPS (Sigma-Aldrich, St. Louis, MO, USA) to $200 \mathrm{~mL}$ of $0.9 \%$ sterile saline. Ten milliliters of SPS solution then was added to each 100-mL aliquot of blood obtained from volunteers [5]. To obtain citrated blood, we used commercial blood collection bags designed for blood donation. Blood was collected from patients who visited our hospital for phlebotomy. Each bag contained 56 $\mathrm{mL}$ of $3 \%$ sodium citrate solution for $400 \mathrm{~mL}$ of phlebotomy. Five milliliters of the anticoagulated blood samples was added to bacteria-inoculated bottles. Final concentration of SPS in the experimental bottle $(0.037 \%)$ revealed the same with the uninoculated bottle $(0.035 \%)$.

A negative control was prepared containing only bacteria except $H$. influenzae which requires blood to grow. The experimental protocol was approved by IRB and blood was collected after receiving written consent from the participants.

\section{Time to detection}

The bottles were preincubated at $25^{\circ} \mathrm{C}$ or $37^{\circ} \mathrm{C}$ for 0,6 , or 12 h. Bottles then were inserted to the BacT/Alert 3D system (bioMerieux Inc.) to measure the time to detection (TTD), defined as the period from the insertion of the bottle to the detection of microorganisms [1]. Mean \pm SD TTDs for the control, SPS blood, and citrated blood were analyzed for each bacterium.

\section{Statistical analyses}

The Mann-Whitney U test was used for the non-parametric analysis of mean TTD differences. The Kruskal-Wallis test was applied to detect differences in the mean TTDs across all preincubation periods. The Jonckheere-Terpstra test was used to measure a decrease in the TTD with preincubation time. All statistical analyses were two-sided and were performed using IBM SPSS v.20.0 software (SPSS Inc., Chicago, IL, USA) at the statistical significance of $P$ value $<0.05$.

\section{RESULTS}

\section{Non-fastidious organisms: $S$. aureus and $E$. coli}

Compared to the control (SA $15.0 \pm 0.6 \mathrm{~h}, \mathrm{SN} 15.0 \pm 1.2 \mathrm{~h}$ ), the cultures containing $S$. aureus plus SPS blood or citrated blood trended toward reduced TTDs under both SA (SPS 13.3 $\pm 1.0 \mathrm{~h}$, citrate $13.1 \pm 1.0 \mathrm{~h}$ ) and SN (SPS 13.1 $\pm 0.9 \mathrm{~h}$, citrate $13.6 \pm 1.2 \mathrm{~h}$ ) bottles (Fig. 1) $(P=0.10)$. However, no significant differences in the TTDs were identified between these two anticoagulants $(P=0.70)$.

The mean TTDs were much shorter for $E$. coli compared with $S$. aureus. Spiking with SPS blood or citrated blood affected less of a reduction in TTDs for E. coli. Mean TTDs in the SA bottles were $12.7 \pm 0.8 \mathrm{~h}$ for the control, $12.0 \pm 0.6 \mathrm{~h}$ for the SPS blood, and $11.9 \pm 0.6 \mathrm{~h}$ for the citrated blood (data not shown, $P=0.40$ ). Mean TTDs were equally $11.4 \mathrm{~h}$ in the $\mathrm{SN}$ bottles for the control, SPS blood, and citrated blood.

\section{Absolute aenobe: $P$. aeruginosa}

TTDs of SA in the control, SPS blood, and citrated blood were similar: $17.6 \pm 0.3 \mathrm{~h}, 16.4 \pm 0.5 \mathrm{~h}$, and $16.5 \pm 0.8 \mathrm{~h}$, respectively $(P=0.10)$ for $P$. aeruginosa.

\section{Fastidious organisms: $S$. pneumoniae and $H$. influenzae}

TTDs of SA in the control, SPS blood, and sodium citrate blood were not significantly different: $14.9 \pm 0.5 \mathrm{~h}, 12.9 \pm 0.5 \mathrm{~h}$, and $13.1 \pm 0.5 \mathrm{~h}(P=0.10)$ in $S$. pneumoniae. TTDs of $\mathrm{SN}$ in the control, SPS blood, and sodium citrate blood were similar: $13.9 \pm 0.2 \mathrm{~h}, 13.0 \pm 0.3 \mathrm{~h}$, and $13.1 \pm 0.4 \mathrm{~h}$, respectively for $S$. pneumoniae. Although TTDs of $H$. influenzae showed a remarkable difference in the SPS blood $(14.8 \pm 0.1 \mathrm{~h})$ vs. citrated blood $(23.5 \pm 1.0 \mathrm{~h})$ in the SA bottles, it was not statistically significant $(P=0.10$, Fig. 2$)$; which showed a similar pattern $(15.0 \pm 1.4 \mathrm{~h}$ vs. $18.3 \pm 0.9 \mathrm{~h})$ in the $\mathrm{SN}$ bottles $(P=0.10)$.

\section{Effect of preincubation}

All experimental bacteria showed a significantly rapid de- 
A

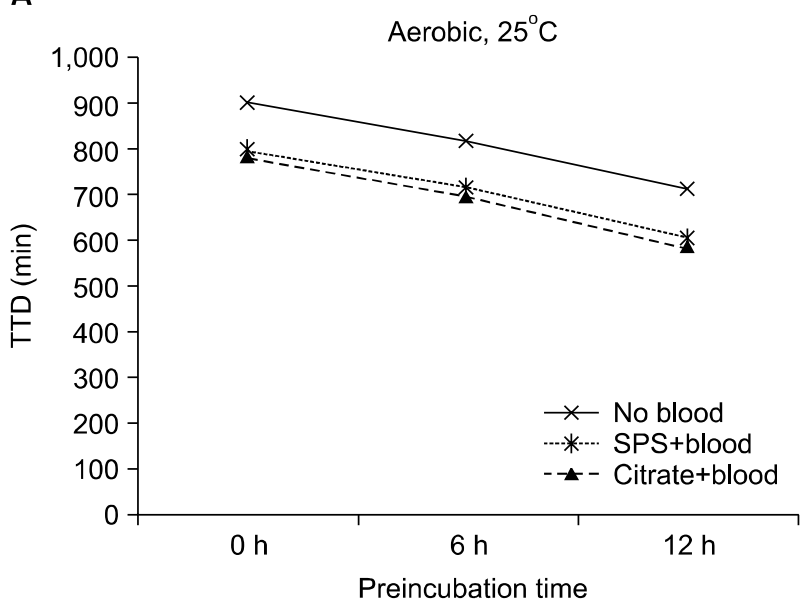

C

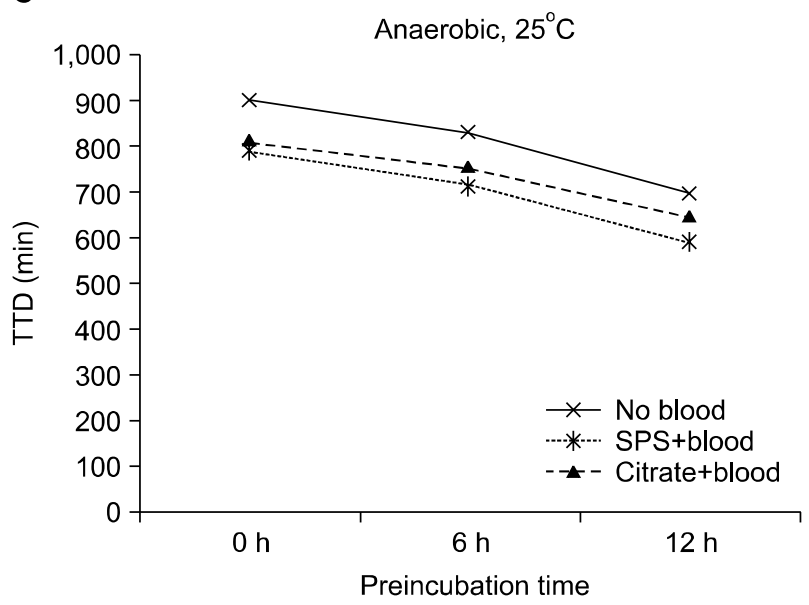

B

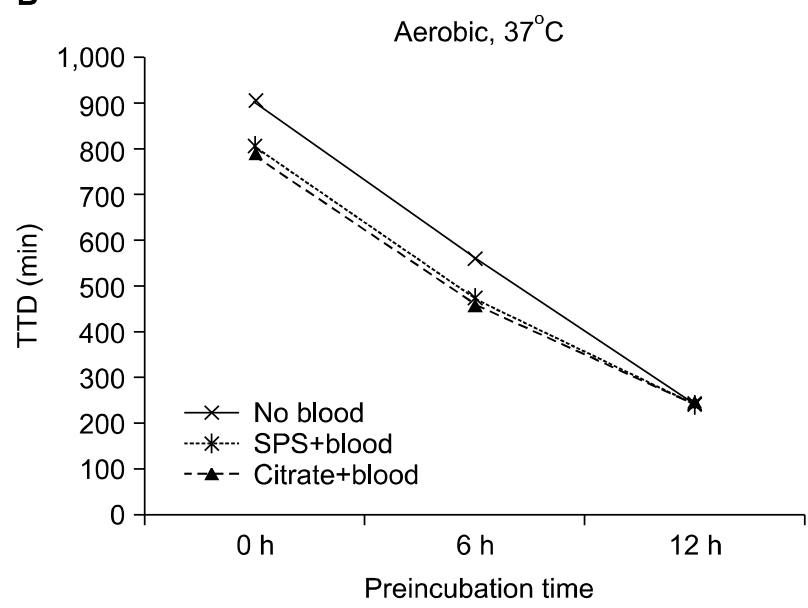

D

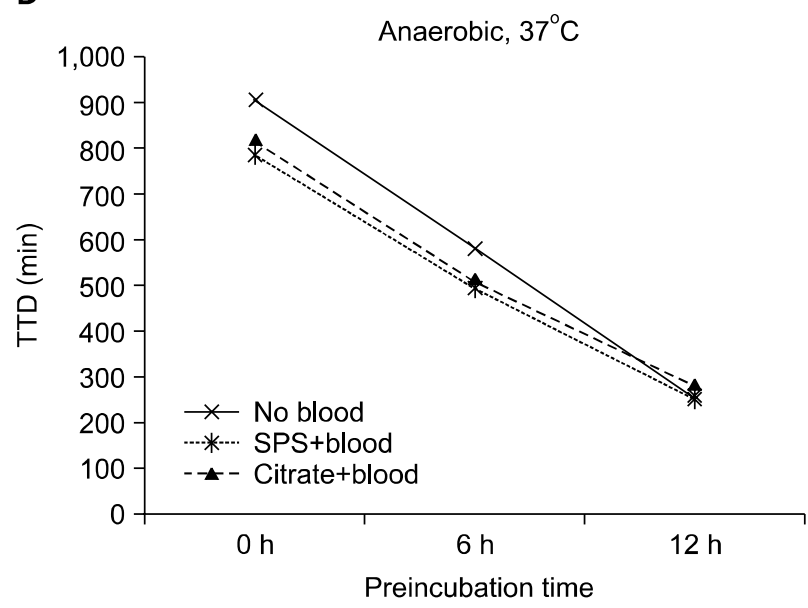

Fig. 1. Effects of blood and the anticoagulants SPS or sodium citrate on the growth (time to detection, TTD) of Staphylococcus aureus in the aerobic and anaerobic bottles by preincubation time. (A) Aerobic bottle, $25^{\circ} \mathrm{C}$. (B) Aerobic bottle, $37^{\circ} \mathrm{C}$. (C) Anaerobic bottle, $25^{\circ} \mathrm{C}$. (D) Anaerobic bottle, $37^{\circ} \mathrm{C}$.

tection by preincubation at $37^{\circ} \mathrm{C}$ for $6 \mathrm{~h}$ or $12 \mathrm{~h}(P<0.05)$. All bacteria showed also significantly shorter TTDs even by preincubated at $25^{\circ} \mathrm{C}$; except $S$. pneumoniae for citrated blood in SA and SN bottles, and SPS blood in SN bottle; H. influenzae for citrated blood in SA and SN bottles, and for SPS blood in $\mathrm{SN}$ bottles (data not shown, $P>0.05$ ).

\section{DISCUSSION}

It seemed difficult to find out the previous studies on the effect of blood on the growth of organisms. Previous studies involving simulated blood cultures examined only SPS blood $[5,6]$, only citrated blood [7,8], or only bacterial inoculation [9]. Depending on components in blood culture, bacterial growth can be either promoted or inhibited. The addition of anti- coagulant-treated blood effected a potential bacterial growth enhancement as suggested by the reduction in TTDs compared with blood-free cultures. Interestingly, this phenomenon was more noticeable in $S$. aureus and $S$. pneumoniae (gram positives) than in $E$. coli and $H$. influenzae (gram negatives). However, it may be plausible to generalize that the addition of blood is somewhat beneficial and/or stimulating to bacterial growth. Theoretically, nutrients and soluble plasma proteins in blood may create a favorable environment for bacteria to proliferate in the absence of certain immune components. The inhibitory effects of cytokines, antibodies, complement molecules, and/or phagocytic cells may be less intense than bacterial growth-promoting factors in the blood. In addition, the anticoagulants may have removed existing immune effectors and thereby allowed for bacterial growth promotion. 

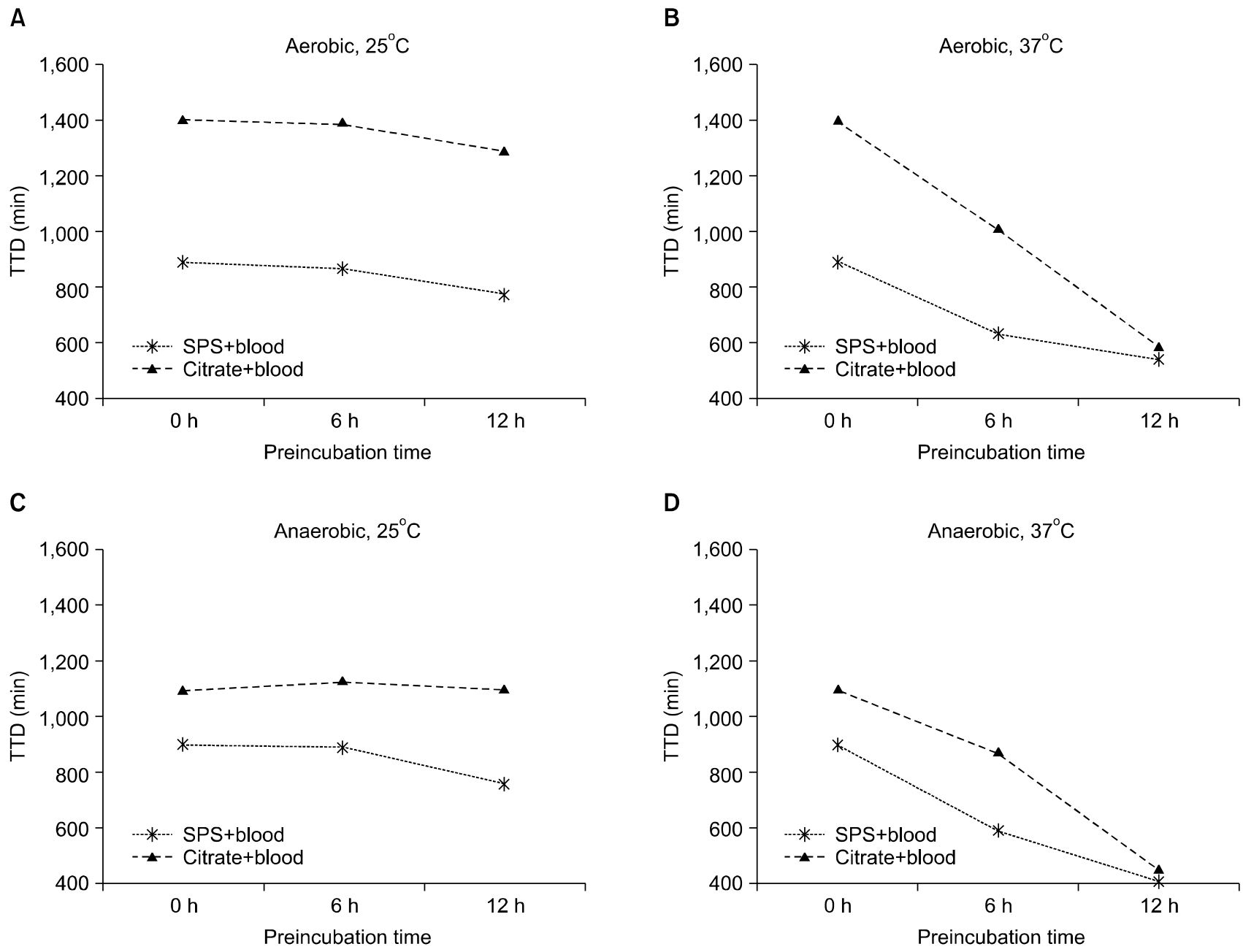

Fig. 2. Effects of blood and the anticoagulants SPS or sodium citrate on the growth (time to detection, TTD) of Haemophilus influenzae in the aerobic and anaerobic bottles by preincubation time. (A) Aerobic bottle, $25^{\circ} \mathrm{C}$. (B) Aerobic bottle, $37^{\circ} \mathrm{C}$. (C) Anaerobic bottle, $25^{\circ} \mathrm{C}$. (D) Anaerobic bottle, $37^{\circ} \mathrm{C}$.

Although SPS is widely accepted as an anticoagulant in blood culture $[1,2]$, it is very hard to prepare a large scale of phlebotomy. Citrate is commonly used for blood donation. The inhibitory effect of citrate was compared with SPS in this experiment with commonly encountered bacteria in the sepsis. TTDs were virtually identical between these two anticoagulants for all bacteria except $H$. influenzae. However, a statistical significance was not found for this organism. Reduction of TTDs was observed with respect to the preincubation time $(6 \mathrm{~h}$ or 12 h) regardless of storage temperature $\left(25^{\circ} \mathrm{C}\right.$ or $\left.37^{\circ} \mathrm{C}\right)$ or bottle type (SA or SN) except $S$. pneumoniae and $H$. influenzae, two fastidious organisms. During preincubation for $6 \mathrm{~h}$ or $12 \mathrm{~h}$, non-fastidious microorganisms might grow significantly either at $25^{\circ} \mathrm{C}$ or $37^{\circ} \mathrm{C}$. In contrast, the fastidious organisms seemed to be more likely indolent by storage at $25^{\circ} \mathrm{C}$, especially in the ci- trated blood.

In conclusion, citrated blood showed comparable TTDs with SPS blood for five experimental bacteria including fastidious organisms. As SPS is difficult to prepare and rarely is used in the laboratory, we may consider using sodium citrate in simulated blood culture experiment.

\section{ACKNOWLEDGMENTS}

This research was supported by the Basic Science Research Program through the National Research Foundation of Korea (NRF), funded by the Ministry of Education, Science, and Technology (2011-0008757). We thank Dr. Rock-Bum Kim (Medical School, Dong-A University) for his excellent assistance with statistical analyses. 


\section{REFERENCES}

1. Wilson ML, Mitchell M, et al. eds. Principles and procedures for blood cultures; approved guideline. Wayne, PA; Clinical and Laboratory Standards Institute, 2007.

2. Thomson R and Miller J. Specimen Collection, Transport and ProCessing: Bacteriology. In: Murray PR and Baron EJ, eds. Manual of Clinical Microbiology. Vol. 1. 9th ed, Washington, DC; ASM Press, 2003:286-330.

3. Reimer LG, Wilson ML, Weinstein MP. Update on detection of bacteremia and fungemia. Clin Microbiol Rev 1997;10:444-65.

4. Kim HJ, Lee NY, Kim S, Shin JH, Kim MN, Kim EC, et al. Characteristics of microorganisms isolated from blood cultures at nine university hospitals in korea during 2009. Korean J Clin Microbiol 2011;14:48-54.

5. Sautter RL, Bills AR, Lang DL, Ruschell G, Heiter BJ, Bourbeau PP. Effects of delayed-entry conditions on the recovery and detec- tion of microorganisms from BacT/ALERT and BACTEC blood culture bottles. J Clin Microbiol 2006;44:1245-9.

6. Chapin K and Lauderdale TL. Comparison of Bactec 9240 and Difco ESP blood culture systems for detection of organisms from vials whose entry was delayed. J Clin Microbiol 1996;34:543-9.

7. Viganò EF, Vasconi E, Agrappi C, Clerici P. Use of simulated blood cultures for time to detection comparison between BacT/ ALERT and BACTEC 9240 blood culture systems. Diagn Microbiol Infect Dis 2002;44:235-40.

8. Akan OA and Yildiz E. Comparison of the effect of delayed entry into 2 different blood culture systems (BACTEC 9240 and BacT/ALERT 3D) on culture positivity. Diagn Microbiol Infect Dis 2006;54:193-6.

9. Klaerner HG, Eschenbach U, Kamereck K, Lehn N, Wagner H, Miethke T. Failure of an automated blood culture system to detect nonfermentative gram-negative bacteria. J Clin Microbiol 2000;38: 1036-41. 
$=$ 국문초록=

\title{
혈액배양에서 구연산 항응고제가 세균 증식에 미치는 효과
}

\author{
경상대학교 의과대학 ${ }^{1}$ 진단검사의학교실, ${ }^{2}$ 응급의학교실, 건강과학연구원 \\ ${ }^{3}$ 성균관대학교 의과대학 삼성서울병원 진단검사의학교실 \\ 이동현 ${ }^{1}$, 고은하 ${ }^{1}$, 최새롬 ${ }^{1}$, 김선주 $^{1}$, 김동훈 $^{2}$, 이남용 $^{3}$
}

배경: 항응고제(sodium polyanethol sulfonate, SPS와 구연산)가 패혈증에서 중요한 5가지 세균의 증식에 미치는 효과에 대해서 관찰하였다.

방법: 세균 150 개 집락을 호기성병(SA)과 혐기성병(SN)에 접종하고, $\mathrm{SPS}$ 혈액과 구연산 혈액 $5 \mathrm{~mL}$ 를 첨가하였다. 이들 혈액배양 병을 BacT/Alert 3D 장비(bioMerieux Inc.)에 투입하고 배양검출시간을 측정하였다.

결과: 포도알균, 대장균, 녹농균 및 폐렴알균에서는 세균만 넣은 병에 비해 SPS혈액 혹은 구연산 혈액을 넣은 병에서 배양검출시간이 1-2시간 단축되었다. 하지만 SPS혈액과 구연산 혈액 간에 차이는 없었다. Haemophilus influenzae는 SPS 혈액(SA 14.8시간, SN 15시간)과 구연산 혈액(SA 23.5시간, SN 18.3시간) 간에 뚜렷한 차이가 있었지만 통계적으로는 유의하지 않았다 $(P=0.10)$

결론: 혈액 주입으로 세균의 증식이 촉진되었고, SPS혈액에 비해 구연산 혈액의 세균 증식 억제 효과는 발견되지 않았다. 따라서 혈액배양 실험에 검사실에서 쉽게 구할 수 있는 구연산 혈액을 사용할 수 있을 것으로 판단된다. [Ann Clin Microbiol 2013;16:168-173]

교신저자 : 김선주, $660-702$, 경남 진주시 강남로 79

경상대학교 의과대학 진단검사의학과

Tel: 055-750-8239, Fax: 055-762-2696

E-mail: sjkim8239@hanmail.net 